\title{
Hospice møter døendes helhetlige behov
}

Et godt utformet hospice gir palliative pasienter og deres nærmeste rom for fellesskap, rekreasjon, kreativitet og spiritualitet.

\section{Forfattere}

\section{Ellen Lykke Trier}

Sykepleier med mastergrad

Peer Gynt helsehus

\section{Nøkkelord}

\begin{tabular}{|l|l|l|}
\hline Dødelig syk Arkitektur & Kunst palliativ omsorg
\end{tabular}

Sykepleien 2017 105(9)(38-40)

DOI: https://doi.org/10.4220/Sykepleiens.2017.63703

\section{HOVEDBUDSKAP}

Døende trenger fred og ro, private rom og rom for fellesskap. Døende ønsker å beholde sin autonomi og leve så normalt og meningsfullt som mulig sammen med sine nærmeste. Hospice er designet for behovene til døende og deres familier. I Danmark har arkitekter utviklet modellen for «Det Gode Hospice i Danmark». I Norge er omsorgen for døende inkludert i den eksisterende helsetjenesten, som begrunnes med at hospicefilosofien kan implementeres overalt. Er det virkelig så enkelt?

«Å komme hit var som å komme fra Tokyo til setra!», sa pasienten som kom fra sykehusets kreftavdeling til Lindrende enhet. Jeg har samme erfaring fra Hospice Lovisenberg. Pasienter og pårørende falt til ro, og institusjonen minnet lite om et sykehus. Omgivelsene var tilpasset den spesielle situasjonen den syke og familien var i, og personalet hadde tid til å ta vare på både den syke og de nærmeste. 
Både Hospice Lovisenbergs døgnenhet og Lindrende enhet i Moss ble bygget med intensjonen om å romme alvorlig syke og døende samt deres nærmeste. De fleste palliative tilbud som eksisterer i Norge i dag, har blitt til i omvendt rekkefølge, der de døende må tilpasse seg rammene i den eksisterende helsetjenesten.

\section{God utforming er viktig}

Hospicebevegelsens mor, Cicely Saunders, gikk svanger med planene om et hjem for døende i over 20 år. Hun hadde mange års erfaring som sykepleier, sosialarbeider (sosionom) og lege i sykehus, og hadde dermed klare tanker om hvilke omgivelser døende og deres pårørende hadde behov for.

Et hospice skulle være et sted der pasienter og pårørende kunne leve sammen den siste tiden. Familierelasjonenes betydning og et helhetlig menneskesyn var styrende prinsipper for den fysiske utformingen av et hospice (1).

I likhet med Florence Nightingale var Saunders opptatt av at pasientrommet måtte utformes etter utsikten fra pasientsengen. Senger måtte kunne trilles ut $\mathrm{i}$ fellesrom, ut på balkonger og ut i hager. Estetikk, planter, kunst og musikk var viktige elementer i hennes første modellhospice (1).

Et hospice skulle være et gjestfritt og innbydende «hjem» der pasienters og pårørendes behov skulle være styrende for arkitekturen. Arkitektens utfordring ble å skape et hjem som kunne romme både pasienter og deres nærmeste, der det var rom for fellesskap, rekreasjon, kreativitet og spiritualitet.

\section{Arkitekturen påvirker}


Jeg har selv merket hvor viktig arkitekturen er. En novemberdag kjørte jeg mot det nye sykehuset jeg ikke hadde sett ennå. Jeg hadde en uro i kroppen og raskere puls enn vanlig; en av mine «egne» befant seg i en ambulanse lenger fremme. Hvite, enorme blokker på et jorde kom til syne.

Idet vi nærmet oss, så jeg en kunstinstallasjon med noen digre, røde pigger. Det føltes som om de skulle spidde meg. Vi passerte et rustent reisverk av et hus foran inngangspartiet. Gjennom glassveggen så jeg en skulptur som minnet om et hvitt spøkelse. Det gikk et gufs gjennom meg.

Midt i kaoset undret jeg meg over hvem man hadde hatt i tankene da man tegnet dette sykehuset, og hva man ville med utsmykningen. Hva med de redde pasientene som ikke vet hva som er galt med dem? Pårørende som skjelvende skal inn for å ta avskjed med sine nærmeste, eller en nervøs mor som skal føde for første gang? Jeg skulle ønske at byggherren og arkitekten hadde spurt dem: «Hva er det dere trenger?»

Hvis en arkitekt hadde spurt meg, hadde jeg svart én ting: «Trygghet.» I disse omgivelsene kjente jeg meg ikke trygg. Jeg lengtet hjem umiddelbart, og det var kanskje meningen?

\section{Ta rommet på alvor}

Sykepleieteoretiker Kari Martinsen har gjennom studier utforsket rommets betydning. Mennesker søker rom som skaper trygghet og gir en opplevelse av å bo og være, mens sykehus er designet for nytte og produktivitet. I denne spenningen av ulike livsfortolkninger befinner den syke seg (2).

\section{三 «Mennesker søker rom som skaper trygghet og gir en opplevelse av å bo og være, mens sykehus er designet for nytte og produktivitet.»}


Karen Marie Dalgaard, som er sykepleier og forsker, fant i sitt doktorgradsarbeid at den romlige dimensjonen hadde stor betydning for uhelbredelige pasienters livsutfoldelse, både alene og sammen med de pårørende.

Hennes empiriske data viste at pasientene opplevde at livsutfoldelsen ble utfordret under opphold på sykehus. De beskrev det som en følelse av å være hjemløs. Stress på grunn av støy og aktivitet førte til dårlig nattesøvn og kjedsomhet fordi pasientene ikke kunne følge sin egen rytme eller hadde rom å utfolde seg i (2).

Mangel på private frirom, forstyrrelser fra personalet og travelhet forplantet seg til pasientrommet og fortrengte pasientens eksistensielle rom. Beskjeden og vissheten om at man skal dø av en uhelbredelig sykdom, fremkaller eksistensielle livsfenomener som utrygghet, frykt, angst, meningsløshet, fortvilelse og håp. Arbeidet med å finne mening med det livet man har levd, og forsone seg med døden, krever en ytre ro og et personale som har tid til å lytte og være til stede (2).

\section{Døendes ønsker og behov}

Sandsdalen og medarbeidere (2015) har gjort en systematisk gjennomgang av studier om døendes egne ønsker og behov i den siste tiden (3). Hun fant fire temaer som var viktige for pasientene:

- Betydningen av å leve et så meningsfylt og normalt liv så lenge som mulig. Det var viktig for den døende å få bevare selvrespekten og bli møtt individuelt med oppfølging basert på personalets kjennskap til vedkommendes historie og verdier.

- Betydningen av at helsepersonell er sensitive for pasientens $\varnothing$ nsker og preferanser og ser hele familien. Pasientene ønsket et godt forhold til helsepersonell basert på tillit, respekt, vennlighet, tålmodighet og medfølelse. De ønsket også kompetent personale som gir god smerte- og symptomlindring, psykososial støtte og praktisk 
hjelp. Videre ønsket de mulighet til å praktisere troen $\sin$.

- Pasientene ønsket å være med på å utforme sin egen behandling og omsorg og ville ha autonomi og kontroll. Studien viste at de hadde forskjellige ønsker om medbestemmelse.

- De fysiske omgivelsene og atmosfæren i omsorgsmiljøet var viktige for pasientene i den siste tiden. Pasientene ønsket å få omsorg i et miljø som føltes trygt, avslappet og vennlig. De verdsatte både privatliv og muligheten til å kunne omgås andre pasienter. Pasienter ønsket medbestemmelse i egen omsorg og død. (3).

\section{Erfaringer med hospice}

Sandsdalens studie om de døendes ønsker og behov sammenfaller godt med Saunders' hospiceverdier og prinsipper slik hun formulerte dem allerede på 1960tallet (1). En norsk studie av pasienters opplevelse av kvalitet i palliativ omsorg viste at pasientene var mer fornøyd med dag- og døgntilbud på hospice sammenliknet med palliativ enhet i sykehjem eller hjemmesykepleie (4).

En studie fra Danmark viste at atmosfæren i et hospice er preget av fred og ro. Sanselige og sosiale rom å utfolde seg i ga mening og innhold for den syke. Det fysiske miljøet, med vekt på lys, estetikk og muligheter for livsnytelse, så ut til å være tett forbundet med livsutfoldelse. Syke mennesker merket at de var i live, at de var til (2).

\section{三 «Syke mennesker merket at de var i live, at de var til.»}

På hospice var det den syke selv og de nærmeste som styrte dagsrytmen og livet sitt. De hadde sitt eget rom eller leilighet som de kunne innrede som de ville. De fikk lov til å ta med kjæledyr og ha besøk når de ønsket. Pårørende kunne overnatte og spise sammen med den syke. 
Hospicet ga mulighet for både privatliv og fellesskap med andre i samme situasjon. De hadde ulike aktiviteter, slik som sosialt samvær i form av samtaler, felles måltider, sang, musikkgudstjeneste, grillkvelder og annet. Pasientene sa at det var svært viktig å ha nærhet til natur og hage samt mulighet for private frirom både innendørs og utendørs (2).

\section{Palliativ behandling}

I Norge har strategier vært rettet mot å sikre kvaliteten på den palliative behandlingen ved å inkludere palliasjon i den eksisterende helsetjenesten. Alvorlig syke og døende henvises til sykehus, sykehjem, hjemmesykepleie eller fastlege i stedet for at myndighetene satser på å etablere egne institusjoner som hospice. I dag er det over 40 palliative enheter $\mathrm{i}$ sykehjem og 100 øremerkete senger for palliative pasienter i sykehjem, men bare fire hospice (5).

Ifølge norske strategidokumenter er «hospice» ikke et entydig begrep, og derfor ønsker palliative organisasjoner og foreninger ikke lenger å bruke begrepet (6). En hyppig brukt påstand er at hospicefilosofien kan virkeliggjøres uavhengig av sted, eksempelvis at en palliativ seng i et sykehjem er likestilt med en palliativ enhet eller hospice (7).

\section{Det Gode Hospice}

Danmark har i dag hospice i alle amt, altså fylker. Uhelbredelig syke kreftpasienter har en lovfestet rett til opphold på hospice. De arbeider for å doble antall hospiceplasser, slik at pasientgruppene med alvorlig hjerte- og lungesyke også kan bli inkludert (8). I Danmark har arkitekter, pasienter, pårørende og fagfolk sammen skapt modellen for «Det Gode Hospice i Danmark» (9). Anne Nissen skriver i forordet til modellen: 
«Hospice er en institution og en del af vort

sygehusvæsen, men med et andet fokus. Derfor skal rammerne være anderledes. Indhold og rammer skal her spille sammen på en ny måde for at nå målet, kvalitet i livet, både for den døende og de nærtstående. Projekt Det Gode Hospice er et ønske om at skabe fornyelse i det danske institutionsbyggeri. Et ønske om at få rammer, indhold og behov til at smelte sammen i en enhed, som både menneskeligt, fagligt og arkitektonisk støtter op om de mennesker, der skal bruge hospice.» $(9$, s. 1$)$

\section{三 «Danmark har i dag hospice i alle amt, altså fylker.»}

I tillegg til en bred tverrfaglig tilnærming, som for eksempel musikkterapeut, sosionom, prest, psykolog, ergoterapeut, kokk, fysioterapeut, lege og sykepleiere, er frivillige en viktig ressurs i hospice. I Danmark er mer enn 1000 frivillige engasjert i hospicearbeid på ulike måter (8).

\section{Hospice i Norge}

Hospice skaper gode fysiske rammer for livsutfoldelse og fellesskap for de syke og deres familier, på deres premisser. Et godt hospicearbeid kjennetegnes ved at den døendes helhetlige behov og lindring av den fysiske, psykiske, sosiale, åndelige og eksistensielle smerten («total pain») ivaretas på en best mulig måte gjennom tverrfaglig samarbeid.

Med lang erfaring som sykepleier fra både Hospice Lovisenberg og kommunehelsetjenestens palliative tilbud vil jeg påstå at hospice representerer noe helt særegent som vi som samfunn trenger. I en tid hvor overbehandling foregår langt inn i døden, blir det svært viktig å skape gode alternative tilbud til alvorlig syke og døende samt deres nærmeste. 
I dag mangler vi satsing på hospice. Professor i

palliativ medisin, Stein Kaasa, har annonsert en integrasjon av palliasjon i onkologien fra det øyeblikket pasienten får en uhelbredelig kreftdiagnose.

Kaasa hevder at dette er det neste tiårets store satsingsområde (10), i Norge kalt PalliOn-prosjektet (11).

\section{三 «I dag mangler vi satsing på hospice.»}

Min bekymring er at ved å knytte palliasjonsbegrepet enda tettere til onkologien vil arbeidet med å utvikle gode palliative tilbud til andre diagnosegrupper enn kreft stagnere. I dag lever kreftpasienter med uhelbredelig sykdom ofte i mange år. Begrepet palliasjon viser ikke lenger til omsorg og behandling $\mathrm{i}$ livets sluttfase. Jeg mener derfor at hospice både som begrep, filosofi og institusjon bør få sin renessanse i Norge.

\section{Vi trenger hospice}

Vi trenger begrepet «hospice» og institusjoner som hospice fordi de fysiske rammene ikke er likegyldige når du skal dø; det betyr også noe hvor du dør. Ikke minst tar hospice familieperspektivet på alvor da døden er en viktig hendelse i familiers liv. De trenger rom og omgivelser der de kan være sammen med den døende på en god måte.

Et viktig prinsipp i hospicefilosofien er nettopp å skape en åpenhet om døden. Hospice gir et signal til offentligheten om at døden er her; den blir synliggjort. $\AA$ ta avskjed med livet krever de beste betingelsene både for det døende mennesket og de nærmeste. Hospice rommer nettopp den filosofien og innsatsen som tenker nytt om verdier og rammer for livets avslutning i vår tid (9).

\section{Referanser}


1. Du Boulay S, Rankin M, Saunders C. The founder of the Modern Hospice Movement. London: SPCK; 2007.

2. Dalgaard KM. Livsudfoldelse i dødens rum. I:

Dalgaard KM, Jacobsen MH (red). Humanistisk

palliation. Teori, metode, etik og praksis. København:

Hans Reitzels Forlag; 2011 (s. 363-81).

3. Sandsdalen T, Hov R, Høye S, Rystedt I, WildeLarsson B. Patient's preferences in palliative care: a systematic mixed studies review. Palliative Medicine 2015;29(5): 1-21.

4. Sandsdalen T, Grøndahl VA, Hov R, Høye S, Rystedt I, Wilde-Larsson B. Patient's perceptions of palliative care quality in hospice inpatient care, hospice day care, palliative units in nursing homes and home care: a cross-sectional study. BMC Palliative Care 2016;15:79. Tilgjengelig fra:

https://bmcpalliatcare.biomedcentral.com/articles/10.1186/s12904016-0152-1 (nedlastet 17.10.2017).

5. Nasjonalt register av palliative virksomheter. 2017. Tilgjengelig fra: https://www.pallreg.no/ (nedlastet 12.06.2017).

6. Norsk forening for palliativ medisin. Standard for palliasjon. 2004. Tilgjengelig fra:

http://legeforeningen.no/PageFiles/26901/standardforpalliasjon.pdf (nedlastet 12.06.2017).

7. Haugen DF. Samlet livshjelp - ikke sprikende.

Tilgjengelig fra:

http://www.verdidebatt.no/dagnyhaugen (nedlastet 12.06.2017).

8. Hospice Forum Danmark. Alle døende har ret til lindring. 2014. Tilgjengelig fra:

http://www.hospiceforum.dk/ (nedlastet 12.06.2017) 
9. Realdania. Program for Det Gode Hospice i

Danmark. 2009. Tilgjengelig fra: http://arkitektur-

lindring.dk/vidensbank/program-for-det-gode-hospice-

i-danmark/ (nedlastet: 12.06.2017).

10. Kaasa S, Knudsen AK, Lundeby T, Loge JH.

Integration between oncology and palliative care: a

plan for the next decade? Tumori Journal

2017;103(1):1-8. Tilgjengelig fra:

http://www.tumorijournal.com/article/cfa67d43-4ea2-

4918-a95e-635d6ff95831 (nedlastet 12.06.2017).

11. Pallion. 2017. Tilgjengelig fra: https://pallion.no/ (nedlastet 12.06.2017). 